Review Scientific Article

Received 03.03.2017.

Approved 04.05.2017.

\title{
MIGRANT CRISIS \\ AND STRENGTHENING OF THE RIGHT WING IN THE EUROPEAN UNION**
}

Migrant crisis, slow economic growth and growing disillusionment with the European Union led to strengthening of far-right parties that have achieved electoral success in a number of European countries. The collapse of the national economy has created a huge number of unemployed. New problems such as migrant crisis foster instability in the EU particularly due to the terrorist acts (Paris, Brussels) and other forms of violence (Cologne, Vienna) that involved migrants from the Middle East. What could represent the biggest problem is the ability of the European radical right parties to constitute it on the joint basis regardless different political backgrounds. The Alliance of European National Movements was formed in Budapest in 2009. Migrant crisis underlined divisions within the European Union, which led to the radicalization of European political scene.

Key words: migrant crisis, European Union, extreme right parties, immigrants

* Mr sc. Milijana Ratković, Senior Research Assistant, University for Business, Engineering and Management PIM Banja Luka, Study Centre Trebinje, email: milijana_rs@yahoo.com

** The abstract of this paper is presented on conference: Innovative Ideas in Science (IIS) and Social and Technological Development (STED), Baia Mare, Romania $10^{\text {th }}-11^{\text {th }}$ November 2016. 


\section{Introduction}

Migrant crisis, which has been shaking Europe for some time now has led to an increase in support for extreme right parties across the continent. Far-right parties are quite diverse, ranging from right-wing parties that are perfectly integrated into the institutional political structure such as the UDC in Switzerland, to the openly Nazi parties like the "Golden Dawn" in Greece, Jobbik in Hungary or Northern League in Italy. They share an extreme nationalism, islamophobia, xenophobia, racism, hatred of immigrants - particularly "non-Europeans" and the Roma.

In 2014 Pew Research Center showed that the majority of respondents who identify themselves as political right wing wanted to limit the number of new immigrants coming into their countries. European elections 2014 confirmed this tendency. The extreme right parties in several developed European countries are second or third in strength and popularity in national parliaments. Their standpoint on globalization, integration and migration is that they have negative consequences for Western Europe society. These parties established their programs around different approach towards "those who are different" and they perceive the EU as a space reserved for predominantly domicile population. Fear of ideological heritage that these movements share is constantly present in Europe, because we are aware that these ideologies have led to millions of deaths and massive violations of human rights. Highlighting diversity of cultures, traditions and lifestyles of immigrant they encourage fear, distrust and outright hostility, which in some cases result in xenophobia and racism in relation to newcomers. Moreover, immigrants are considered to be a threat to national cohesion, national culture and national "way of life".

The so-called "nativism" plays an important role in the ideology and program orientation of extreme right parties i.e. the notion that a country should be inhabited only by the members of local ethnic communities because all foreign elements (both persons and ideas) undermine the nation-state. According to some sociologists this is "ethno-nationalist xenophobia", which aims to strengthen the nation by homogenization, return to traditional values and remove from society any groups that allegedly threaten the majority community. ${ }^{1}$

The European Union is based on the values of respect for human dignity, liberty, democracy, equality, the rule of law and respect for human rights, including the rights of minorities. However, the spread of terrorist attacks outside the Middle East and a large influx of refugees driven by repression and conflict prompted many governments to reduce human rights in an effort to protect their own safety. Professor Čehulić believes that the migrant crisis revealed certain forms of hypocrisy in the behavior of the European Union. "The European Union is founded on the principles of equality, freedom and human rights,

Rydgren, J. (2010): "Radical Right-wing Populism in Denmark and Sweden: Explaining Party System Change and Stability”, SAIS Review, 30/1, 57-71. 
but on the issue of migrant crisis the EU violated these principles. The EU also showed the dispersion of relations of certain EU member states towards migrant crisis. Hungary, Czech Republic, Slovakia and Poland have put national interests ahead of the common principles of the EU".

The report by Human Rights Watch states that "Fear of terrorist attacks and mass refugee flows are driving many Western governments to roll back human rights protection and measures adopted by the French government after the terrorist attacks in Paris, such as the state of emergency. Search of apartments without prior approval of the competent judicial authority is a backward step that threatens the rights of all without any demonstrated effectiveness in protecting ordinary people"3 says Human Rights Watch. Without doubt significant social and ideological changes are happening at the European political scene, while the radical or new European right wants a strong return of the nation state, which, in their interpretation, appears to protect against "invasion of foreigners". They appeared in the European Parliament with this attitude as a fraction that should not be underestimated. The growing popularity of these parties and their impact on the general policy caused the most concern among European liberals, fearing that European democratic system in Europe could be threatened.

\section{The theoretical framework of the extreme right}

The radical or extreme right wants a strong return of the nation state which in their interpretation appears as a "protector" against the invasion of the foreigners.

Despite the fact that these parties represent movements in different countries, there is a common ground which they all share. They are generally right and extreme-right, xenophobic, nationalist movements. They are authoritarian, only quasi-democratic, in internal and external practices, often with charismatic leaders, and their distinguishing policies are anti-European, anti-immigrant, islamophobic and intolerant. ${ }^{4}$

"Right wing" is best defined as an ideology that accepts or supports a system of social hierarchy or social inequality" ${ }^{5}$ According to Wilhelm Heitmeyer, right wing extremism encompasses the most important overlaps in a broad spectrum

2 Čehulić, L. (2016): Globalni procesi i bezbjednost na jugoistoku Evrope, FriedrichEbert-Stiftung, Banja Luka www.slobodnaevropa.org/a/nve-migrantska.../27665151.html (18.1.2017)

$3 \quad$ World Report 2016: 'Politics of Fear' Threatens Rights, Terror Attacks, Refugee Crisis, and Broad Global Crackdown https://www.hrw.org/news/2016/01/27/world-report-2016-politics-fear-threatens-rights (12.12.2016)

$4 \quad$ Ford, G. (2014): How can the European left deal with the threat posed by xenophobia? Center for Labour and Social Studies, London, 7.

5 Carlisle P. R. (2005): Encyclopedia of politics: the left and the right, Volume 2, University of Michigan, Sage Reference, 693- 721. 
ranging from right wing populism bordering on ultraconservative democratic forms at one end, to neo-Nazism at the other, as a variant that carries particularly heavy historical charge. If we survey the ideological components of rightwing extremism it becomes apparent that they may be directed both toward the structure of the political system and the organization of social coexistence. ${ }^{6}$

The ideology of inequality is expressed in extreme nationalism, racism, social Darwinism, in totalitarian standards, with special emphasis on the homogeneity of such groups. A belief that violence is a legitimate way of dealing with the conflict leads to acceptance of its use. ${ }^{7}$

What far-right parties definitely have in common are: nationalism, racism, strong state and hostility to democracy. Professor Golder divided far-right parties into two groups: the populist and neo-fascist. ${ }^{8}$ All nationalist parties attempt to reserve power for their group. This is why nationalists are against internationalism as it cedes power out of their country. ${ }^{9}$

Right parties are defined by the ideology that either accepts or supports the system of social inequality and they strongly oppose the idea that immigrants should have the same treatment as locals.

Radical right-wing populist parties tend to distinguish themselves by the radical rejection of the established socio-cultural and sociopolitical system, their pronounced advocacy of individual achievements, a free marketplace, and the drastic restriction of the role of the state, their rejection of the individual and social equality, their opposition to social integration of marginalized groups and the extension of democratic rights to them and their promotion of xenophobia, if not overt racism, their populist instrumentalization of diffuse public sentiments of anxiety, envy, resentment and disenchantment and their appeal to allegedly superior common sense of the common people against the dominant cultural and political consensus. ${ }^{10}$

In recent years, parties opposing immigration have registered significant growth including the countries that are considered to be very liberal with tolerant voter base. During the previous period, the election results and opinion polls in many European countries showed the strengthening of electoral support for the movements that claim to defend the interests and culture from immigrants

6 Heitmeyer, J. H. (2003): Violence: The Difficulties of a Systematic International Review. Kluwer Academic Publishers, Dordrecht, 401.

7 Zick, A. K., Küpper, B., Hövermann, A., (2011): Intolerance, Prejudice and Discrimination, A European Report. Friedrich-Ebert-Stiftung, 25. http://library.fes.de/pdf-files/do/0790820110311.pdf (12.1.2017)

8 Golder, M. (2003): Explaining Variation in The Success of Extreme Right Parties in Western Europe. Comparative Political Studies, 459.

9 O'Malley, E. (2008). Why is there no Radical Right Party in Ireland? West European Politics, 31/5, 973.

10 Betz, H. G. (1993). The Two Faces of Radical Right-Winged Populism in Western Europe. The Review of Politics, 55/4, 664. 
and the spread of Islam. The increase in support for these parties is indisputable so that in some of the European countries these parties have become second largest with about $30 \%$ of voters support and in some cases government formation depends on their support or they even participate in the ruling coalition. Their election success is quite challenging for moderate orientation parties to compete against. According to Saull "the far right ideological armory consists of a tendency towards xenophobia, "racial exclusionism" and a commitment to institutionalizing and upholding inequalities in the spheres of gender, race, nationality and ethnicity, that combine with a strong dosage of anti-individualism, whereby the autonomy of the individual is supposed to submit to the will of the nation via the state". ${ }^{11}$

On the other hand economic downturn is always fertile ground for nationalism. Economic crisis that began in 2008 deepened social differences between extremely rich and the increasing number of the poor. The collapse of national economies made huge number of the unemployed. In many European countries animosity towards immigrants is thriving and they are perceived as a threat to national unity, culture and national "way of life". And by using populist rhetoric these parties "appeal to the allegedly superior common sense of the common people against the dominant cultural and political consensus".

Professor Kitschelt points out that significant support for the parties of the extreme right comes from the voters' fear about the future of the social welfare state. "Income redistribution and protection from the risks of labor market can be woven into racist authoritarian message by appealing to "welfare chauvinism". The welfare state is presented as a system of social protection for those who belong to the ethnically defined community and who have contributed to it. Immigrants are depicted as free-loaders who do not contribute to the system but claim its benefits. ${ }^{12}$

Elections for the European Parliament held in June 2009 showed a tendency of "turning right". Then the BNP (British National Party ) won nearly a million votes (6\% of total votes), while for example the Austrian Freedom Party won 12, $7 \%$, and the Hungarian Jobbik, known for open anti-Semitic and a anti-Roma rhetoric, won even $14.67 \%$ of total votes.

Speaking about the profile of an extreme right voter, research shows that it is predominantly working class with primary and secondary education as well as young unemployed people. However, there are also those with higher education who think that globalization, integration and a massive influx of foreigners reduce their national sovereignty, weaken their national identity and think that immigrants devalue their traditional culture. They are not so much "driven by

11 Saull, R. (2013): Capitalism, crisis and the far right in the neoliberal era, Journal of International Relations and Development, 18/1, 7.

12 Kitschelt, A. J. (1997): The Radical Right in Western Europe: A Comparative Analysis. University of Michigan Press, 22. 
economic motivations, but regard the impact of migration as a deadly threat to national identity. Basically, they are concerned about the "levelling down" of their own cultures as a result of "hybridization." The fact that there are substantial differences in the percentage of middle-class educated people supporting the new radical right in countries such as Austria or Denmark, compared to Britain, where radical right support remains a primarily working class phenomenon, adds to the complexities involved in sketching the socio-economic profile of the new radical right voter. ${ }^{13}$ Some surveys showed that radical right electorate could be divided into three groups: 1) supporters who are discontented with their jobs, employment, social status or standard of living 2) supporters with a feeling of fear or anxiety because mainstream parties are unable to solve problems of economic stagnation or employment issues for example, 3) supporters who were promoted in their jobs and feel greatly attached to the company and its goals, so they want to preserve achieved results and values. ${ }^{14}$

\section{The rise of the radical right in Europe}

We have witnessed the (un)expected rise of xenophobia in the most developed European countries and strengthening of political parties that base their program on anti-Semitism, islamophobia and racism while in most cases the EU members turn a blind eye to hate speech.

Peace as the essence of the European Union is being threatened by the worst xenophobic and racist concepts while the pressure of the economic crisis makes a fertile ground for populism.

During the Cold War the Soviet Union and communism were perceived as the "evil empire". After disintegration of bipolar system this perception disappeared. It was replaced by terrorism that has become the new figure of the enemy for the right-wing populist ideology.

Through a mix of rude political messages, vaguely communicated ideas and bad faith, the radical right abuses the principle of freedom of speech. The problem begins when these ideas turn into violence. We have witnessed that Dutch court did not sentence Geert Wilders for hate speech. Leader of Dutch Freedom Party was released from the charges of hate speech and as it was explained his statements and the controversial film represented "freedom of speech", extreme one, though. The phenomenon of rising popularity of the right wing parties in

13 Guibernau, Monserrat (2010): Migration and the rise of the radical right, Social malaise and the failure of mainstream politics, Policy Network Paper, Barrow Cadbury Trust, 9. http://www.policy-network.net/publications/3690/Migration-and-the-rise-of-the-radicalright(12.12.2016).

14 Flecker J., Hentges G., Balazs G. (2007): “Potentials of Political Subjectivity and the Various Approaches to the Extreme Right: Findings in the Qualitative Research", 60, in J. Flecker (ed.) Changing Working Life and the Appeal of the Extreme Right, Aldershot 
the Nordic States should not be underestimated. For decades these states represented refuge to the number of immigrants from conflicted third world countries. In 2010 general election the Swedish Democrats for the first time surpassed $4 \%$ threshold in order to enter parliament. This increase in popularity is similar to other anti-immigration movements in Europe. Their success is based on the most rigid political concepts with programs based on anti-Semitism, islamophobia and rejection of multiculturalism.

Austria Austrian far-right Freedom Party (FPO) had significant success in local elections and secured 18 seats in the Upper Austria. They won 12,71\% in the European Parliament elections in 2009 while this percentage in 2014 was 19.72\%. Dramatic Austrian presidential election in 2016, when Norbert Hofler lost for less than one percent, confirmed the rise of the right wing in the country. The next general election in Austria will be held in 2018. FPO is extreme right party that stands out for the preservation of national identity, non-implementation of EU decisions in Austria and prevention of Muslim countries to become EU members.

In Poland The right-wing Law and Justice Party won 39 percent on parliamentary elections held on 25 October 2015 and formed the Polish government.

In Hungary Viktor Orban's Fidesz won a majority in parliamentary elections twice in a row, while the extreme right-wing party Jobbik won 20 percent in 2014. Jobbik claims to be "the strongest national radical party" in the EU, and Hungary's second largest political party and the fact is that Jobbik continuously increases its popularity. European economic crisis alone cannot explain the rise of Jobbik. "Its success is linked to the failure of the transition process after the 1989 revolution to address more fundamental concerns of Hungary's national identity". ${ }^{15}$

The right-wing Alternative for Germany (AFD) won in three provinces in March regional elections, and at the national level they won 10 to $12 \%$. As many as 20.000 people gathered in Dresden to protest against migrants while one of the speakers expressed regret that the "concentration camps were closed." Migration has become a heavily politicized issue in Germany. The increase in violence towards immigrants is evident. In 2015 there were 429 attacks on refugee camps. AFD continued victories at regional level in September elections 2016.

Radical parties strengthened even in the so-called welfare states such as Sweden. The far right Sweden Democrats took the third place in the national elections in September 2015 with almost 13 percent of the vote and won enough seats to block legislation.

The far-right Danish People's Party (DF) has been successful in the last year elections in the country with $21.1 \%$ of votes and 15 seats in the national parliament. In the European Parliament elections DF doubled its seats (from 2 to 4 ) and won 27 percent of the Danish vote.

15 Dettke, D. (2014): Hungary's Jobbik Party,the Challenge of European Ethno-Nationalism and the Future of the European Project, Centre for International Relations, 4/2014, 25. 
Similar to the Danish People's Party, Finnish nationalist party known as the real Finns experienced a meteoric success in the elections and became the most important player in the coalition government. They won $17.7 \%$ of the votes in the elections in April 2015 and joined a coalition with the ruling conservatives. Concern over the influx of migrants has increased the party's popularity and the polls at the time showed that $51 \%$ of supporters believe that "people of a particular race are not able to fit into the society."

France The far-right National Front surprised Europe and the world when it won the first round of French local elections in December 2015. The popularity of Marine Le Pen is further increased after the Paris attacks. The extreme right has won six of the thirteen French regions. The ruling Socialists have not benefited from the increase in the popularity of President Fransoa Hollande, who was strongly supported by citizens in the fight against terrorism after the attacks.

Electoral support for The Front National in its national breakthrough election, election for European Parliament 1984 came largely from voters who previously voted for mainstream right, but who were disappointed after the victory of the left in 1981, and discontented with the (at least perceived) 'soft' line of the mainstream right parties in the early $1980 \mathrm{~s}^{16}$

After success in the European and local elections, the president of the extreme right-wing party announced the candidacy for the upcoming presidential elections in May 2017.

Greek politics has become a tale of two extremes in recent years as the country struggles against the economic crisis and the huge influx of migrants crossing the Mediterranean from neighboring Turkey. Despite the victory of the socialist government in January 2015 Greeks also voted for openly fascist parties such as Golden Dawn. The party won 6.3 percent of the vote, resulting in 17 senate seats in the 300-seat government body. The country is on the front line of the refugee crisis, and it is not surprising that the Golden Dawn is quite popular on the islands of Lesbos and Kos and the Athens region. Greek economic problems and migrants crisis which is still far from over, ignite fear that the Golden Dawn could become an important player in Greek politics in the future.

According to a public opinion survey more and more Italians, even those living in the south of the country expressed support to regional Northern League party and its leader Mateo Salvini. Northern League is one of the most extreme parties in Italy when it comes to foreigners and their exclusion from the Italian society. ${ }^{17}$ Its leader Mateo Salvini accused Pope Francis of betraying Christianity by promoting dialogue with Muslims, while referring to the euro as "crime against humanity ". In the province of Veneto, this party eliminated all refu-

\footnotetext{
16 Rydgren, J. (2004): The Populist Challenge: Political Protest and Ethno-nationalist Mobilization in France, Berghahn Books, New York Oxford, 85.

17 Milardović, A. (2013): Stranac i društvo, Fenomenologija stranca i ksenofobije, Pan liber, Zagreb, 190.
} 
gee centers near tourist sites, arguing that the sight of African migrants have "a devastating effect" on local traders. There is a fear that this extreme right-wing party could make even better political result at the election in May of 2018.

After the Paris attack in November 2015 Dutch extreme right-wing Freedom Party and its leader Geert Wilders surged to the top of Dutch opinion polls. This party won 13.32 \% in the European Parliament elections in 2014. Wilders, known for his agitating speeches, claimed that the West is at war with Islam after the Paris attack. Wilders is under investigation for alleged discrimination and incitement to hatred against Moroccans at conference in Hague, while in 2007 he was under investigation for hate speech. Freedom Party wants the Netherlands to leave the European Union so The Hague can independently decide on its immigration and fiscal policies.

Although Switzerland is not a member of the European Union or Schengen, its elections in 2015 strengthened the position of the right party due to concerns of the refugee crisis. Despite the continuity of radical right-wing populist parties throughout the post-war era and the boost they have experienced since the early 1990s, the idea persists that Switzerland differs from other Western democracies where such parties have achieved notable electoral success. This is based on the notion of "Swiss exceptionalism" implying that Swiss case features particular historical aspects, or aspect of the political system and culture, which are seen as creating contextual conditions that are disadvantageous for the strength of radical right-wing politics. ${ }^{18}$ Ultra-conservative Swiss People's Party, which requires strict immigration quotas, achieved the best election result so far - $29,4 \%$. The increase in support for the far right option was prompted by a series of agreements that Switzerland signed with the European Union, including the agreement to accept mandatory quotas for refugees in accordance with the plan of the President of the European Commission.

According to the UNHCR and the International Organization for Migration (IOM), the number of refugees and immigrants that arrived in the EU in 2015 is over a million while 3,600 of them died or disappeared along the way. Half of them are Syrians fleeing from the war, 20\% of Afghans, and 7\% of Iraqis. Human rights violation, deteriorating security and poverty are also prompting people to flee from the countries such as Iran, Somalia, and Pakistan. Faced with a huge number of immigrants, Hungary was the first to try to block their route with a razor-wire fence. Other countries such as Slovenia and Bulgaria have erected similar obstacles. And several Balkan countries, including Macedonia, have decided only to allow Syrian and Iraqi migrants across their frontiers. As a result, thousands of migrants have been placed in camps in Greece, which has asked the European Commission for nearly $€ 500 \mathrm{~m}$ in humanitarian aid. Accord-

18 Skenderović, D. (2012): Radical right wing populism in Switzerland, 214, in Mammone Andrea, Godin Emmanuel, Jenkins Brian (eds): Mapping the Extreme Right in Contemporary Europe, Routledge, New York 
ing to the EU rule refugees are required to claim asylum in the member state in which they first arrive. ${ }^{19}$ The European Commission estimates that by the end of 2017 that number will exceed 3 million. ${ }^{20}$ And the socialization of migrants from the Middle East certainly represents the biggest challenge for the European Union. The EU now hopes that Turkey can help to reduce the number of migrants arriving in the EU nations. The far-right parties do not consider people coming to Europe from the Middle East as immigrants or refugees but intruders and the fact that migrants are mainly Muslims fits into their extreme right-wing ideology, which perceives such migrants as fighters against "European Christian Tradition". "History shows that the patterns we are witnessing today - distrust and rejection of a minority group, suspicions of their double loyalties, fears of a 'silent colonization' and the introduction of a binary view on the situation - us versus them - are not new, although the scale and pace in which it is taking place in this global era are unparalleled.” ${ }^{21}$

Ivan Krastev believes that the rise of the right-wing parties in the European Union indicates the increasing number of the intimidated majority as a new force in European politics. "The rise of these parties is symptomatic of the explosion of threatened majorities as a force in European politics. They blame the loss of control over their lives, real or imagined, on a conspiracy between cosmopolitanminded elites and tribal-minded immigrants. They blame liberal ideas and institutions for weakening the national will and eroding national unity. They tend to see compromise as corruption and zealousness as conviction. ${ }^{22}$ Pointing out the success of Polish Law and Justice Party, Krastev believes that the populist and radical parties could have devastating effects for the future of the European Union.

19 The Rreform of the Dublin III Regulation, European Parliament, Policy Department, Citizens' Rights And Constitutional Affairs,1-76, http://www.europarl.europa.eu/RegData/ etudes/STUD/2016/571360/IPOL_STU(2016)571360_EN.pdf(25.1.2017)

20 Chadwick V. Burchard von der M. "EU expecting 3 million more migrants by 2017" http://www.politico.eu/article/migrant-crisis-eu-3-million-migrants-news-2017-finance/ (12.1.2017)

21 Ramadan, T. (2010). Migration and the rise of nationalist right-wing parties? Policy Network Paper, Barrow Cadbury Trust, 5. http://www.policy-network.net/uploads/media/160/3768. pdf (12.12.2016)

22 Krastev, I. (2015): "Why Poland Is Turning Away From the West", The New York Times, https:/www.nytimes.com/2015/12/12/opinion/why-poland-is-turning-away-from-thewest.html?_r=0 (21.1.2017). 


\section{Conclusion}

Migrant crisis has shown that EU member states do not have a single policy and that the EU is subjected to destabilization. In very short time the basic principles on which the EU is based (unity, freedom of movement and human rights) have been questioned. Some analysts believe that the list of EU countries that betrayed their core values is quite long. European elections in 2014 confirmed the tendency of "turning right". Far-Right Parties are quite diverse, ranging from openly Nazi parties like the "Golden Dawn" in Greece or Northern League in Italy or Hungary's Jobbik to those that are perfectly integrated into the institutional political structure, such as the UDC in Switzerland. They share chauvinistic nationalism, xenophobia, racism, hatred of immigrants - particularly "the non-Europeans" and the Roma, and islamophobia. Even in Scandinavia, which is considered as the center of tolerance, support for extreme right-wing parties is getting bigger. In addition, the perception that immigrants "steal" jobs from local workers or that asylum seekers or refugees receive bigger social assistance than the citizens in European countries leads to growing resistance or contempt toward the state or society as a whole. This uncertainty of domestic workers on the one hand and diversity of cultures, traditions and values on the other, as well as the fear of different lifestyle of immigrants encourage distrust and outright hostility which in some cases lead to open racism and xenophobia in the relations with the newcomers.

The question is how will European countries deal with immigrants in the future?

In modern political societies, especially constitutional democracies, cultural diversity is a challenge for both - government policy and political theory. It is necessary to find and offer political principles that will allow people of different ways of life to live together. It is a challenge because members of different ethnical groups demand not only their part of economic income distribution but more importantly the recognition of their different identities as members of different cultural communities in the society. This issue opens a fundamental conflict for every political community, i.e. how to reconcile the imperative of individual and universal human rights and ethnic affiliation within political community". ${ }^{23}$ (Podunavac, 2011).

23 Podunavac, M. (2011): “Ustavni identitet i konstrukt „Drugog“. Zbornik radova sa međunarodne naučne konferencije „Država i demokratija u procesu evropeizacije Srbije“, Fakultet političkih nauka, Beograd, 31-45 


\section{References}

- Betz, Hans Georg (1993): “The Two Faces of Radical Right-Winged Populism in Western Europe", The Review of Politics, 55/4, 663-685.

- Carlisle P. Rodney (2005): Encyclopedia of politics: the left and the right, Volume 2, University of Michigan, 693- 721.

- Čehulic, Lidija (2016): Globalni procesi i bezbjednost na jugoistoku Evrope, Friedrich-Ebert-Stiftung. Banja Luka

- $\quad$ www.slobodnaevropa.org/a/nve-migrantska.../27665151.html (18.1.2017)

- Dettke, Dieter (2014): Hungary's Jobbik Party,the Challenge of European Ethno-Nationalism and the Future of the European Project, Centre for International Relations, Warszawa, 25.

- $\quad$ Flecker J., Hentges G., Balazs G. (2007):'Potentials of Political Subjectivity and the Various Approaches to the Extreme Right: Findings in the Qualitative Research', 35-61, in Flecker J. (ed.), Changing Working Life and the Appeal of the Extreme Right, Aldershot: Ashgate, Ashgate Publishing Limit

- Ford, Glyn (2014): How can the European left deal with the threat posed by xenophobia? Center for Labour and Social Studies, London, 7.

- Golder, Matt (2003): "Explaining Variation in The Success of Extreme Right Parties in Western Europe", Comparative Political Studies, 36/4, 432-466.

- Guibernau, Montserrat (2010): "Migration and the rise of the radical right", Policy Network Paper, 9 www.policy-network.net/publications_download. aspx?ID=3684 (12.12.2016)

- Heitmeyer, Wilhelm, Hagan, John (2003): Violence: The Difficulties of a Systematic International Review, Kluwer Academic Publishers, Dordrecht Boston London, 401.

- Kitschelt, Herbert, McGann J. Anthony (1997): The Radical Right in Western Europe: A Comparative Analysis. University of Michigan Press, Ann Arbor 22.

- Krastev, Ivan (2015): "Why Poland Is Turning Away From the West", The New York Times, Dec.11, 2015 https://www.nytimes.com/2015/12/12/opinion/why-poland-is-turning-away-from-the-west.html? $\mathrm{r}=0$ (21.1.2017).

- Milardović, Anđelko (2013): Stranac i društvo, Fenomenologija stranca i ksenofobije, Pan liber, Zagreb, 190.

- O’Malley, Eoin (2008): "Why is there no Radical Right Party in Ireland?" West European Politics, 31/5, 960- 977.

- Podunavac, Milan (2011): Ustavni identitet i konstrukt „Drugog“. Zbornik radova sa međunarodne naučne konferencije „Država i demokratija u procesu evropeizacije Srbije“ Beograd, Univerzitet u Beogradu - Fakultet političkih nauka, 31-45

- Ramadan, Tariq (2010): Migration and the rise of nationalist right-wing parties? Copenhagen: Barrow Cudbury Trust,

- $\quad$ http://www.policy-network.net/uploads/media/160/3768.pdf (12.12.2016). 
- Rydgren, Jens (2004): The Populist Challenge: Political Protest and Ethnonationalist Mobilization in France, Berghahn Books, New York-Oxford, 85.

- Rydgren, Jens (2010): "Radical Right-wing Populism in Denmark and Sweden: Explaining Party System Change and Stability”, SAIS Review, 30/1, 57-71.

- Saull, Richard (2015): "Capitalism, crisis and the far right in the neoliberal era”, Journal of International Relations and Development, 18/1, 25-51.

- Skenderovic, Damir (2012): Radical right wing populism in Switzerland, 214 in Mammone Andrea, Godin Emmanuel, Jenkins Brian (eds): Mapping the Extreme Right in Contempory Europe, Routledge, New York

- Zick Andreas, Küpper Beate, Hövermann Andres (2011): Intolerance, Prejudice and Discrimination, A European Report, Friedrich-Ebert-Stiftung, Berlin, http://library.fes.de/pdf-files/do/07908-20110311.pdf (12.1.2017). 
Mr Milijana Ratković,

Viši asistent, Univerzitet za poslovni inženjering i menadžment Banja Luka, Studijski centar Trebinje

\section{MIGRANTSKE KRIZE I JAČANJE DESNICE U EVROPSKOJ UNIJI}

Migrantska kriza, spor ekonomski rast i sve veće razočarenje Evropskom unijom, doveli su do jačanja krajnje desnih stranaka koje su ostvarile izborni uspjeh u nizu evropskih zemalja. Urušavanje nacionalnih privreda stvorilo je ogroman broj nezaposlenih. Novi problemi poput migrantske krize produbili su nestabilnost u EU posebno nakon terorističkih napada (Pariz, Brisel) i drugih oblika nasilja (Keln, Beč), u kojim su učestvovali imigranti s Bliskog istoka. Ono što bi moglo predstavljati najveći problem jeste sposobnost evropskih radikalno desnih stranaka da se, bez obzira na drugačije političke pozadine, konstituišu na zajedničkoj osnovi. Savez evropskih nacionalnih pokreta nastao je u Budimpešti 2009. godine. Migrantska kriza je naglasila podjele unutar Evropske unije, što je dovelo do radikalizacije evropske političke scene.

Ključne riječi: migrantska kriza, Evropska unija, radikalna desnica, imigranti 